\title{
THE SERBIAN PEOPLE AND THE EUROPEAN UNION: A SAD STORY WITH AN UNPREDICTABLE END ${ }^{2}$
}

https://doi.org/10.18485/iipe_balkans_rssc.2020.ch14

\begin{abstract}
In this text, the author analyzes the European Union's attitude towards Serbia and the Serbian people over the last thirty years since the beginning of the breakup of the SFR Yugoslavia. He claims the hostile attitude of Brussels towards Serbia and the Serbian people has not changed since the regime's demise in 2000. By showing examples of EU involvement in the processes of the secession of Kosovo, the separation of Montenegro, support to the work of The Hague Tribunal (ICTY), relations toward the privatization process in Serbia, issues of the position of minorities, etc., the author argues that the process of European integration of Serbia was used as a framework for completing the pre-planned process of the dissolution of the SFRY. Instead of the EU being guided by the normative Copenhagen criteria and the previous enlargement practices, it is actually geopolitical demands, which are detrimental to the interests of the state of Serbia and the Serbian people as a whole, that are dominating in relations toward Serbia.

Keywords: Serbia, European Union, Yugoslavia, conditionality, geopolitics, European integration.
\end{abstract}

\section{INTRODUCTION}

This year Serbia is marking thirty years of the introduction of liberal democracy or party pluralism in Serbia, but also from the beginning of the breakup of Yugoslavia. However, it is also the twentieth anniversary of the so-called democratic changes and the beginning of the European integrations of Serbia. While in the first ten years, Belgrade has had a clear

\footnotetext{
${ }^{1}$ Principal Research Fellow, Director of the Institute of European Studies, Belgrade. E-mail: mdjurkov@gmail.com.

${ }^{2}$ This article is a kind of an ongoing project. The first version was published in Serbian in the Kultura polisa journal (Đurković, 2014). Over time more and more facts have emerged that corroborate its main thesis, so I have decided to publish a new, updated version, for the first time in English.
} 
geopolitical opposition to the entire Western world, including Brussels, the following two decades have been marked by the Western world's complete dominance of our domestic politics and orientation. During those two decades, European integration has been a clear priority for the Serbian authorities. It seems that the time has come to assess this whole period and evaluate what such status has brought to Serbia. The starting hypothesis is that the policy of the West towards Serbia, even after Milošević, retained the same geopolitical premises and that the framework of the process of European integration of the country was additionally used to implement the same goals. ${ }^{3}$

The history of the European idea in our region dates long before the contemporary period. In the 1930s, a number of intellectuals or even circles, such as Curčin's New Europe, were involved in a network of pan-European movements, federations, congresses, leagues for peace and human rights, all of which sought together to make sense of a framework for European peace, development or even a European federation. It was a very wide range of ideas, involving great thinkers such as Živojin Perić, as well as the obscure Dimitrije Mitrinović. ${ }^{4}$

The ideology of the second Yugoslavia was opposed to the capitalist world, and its foreign policy orientation was based on balancing between the blocs and pushing its goals through the non-aligned movement. However, archival material and published memoirs show that the process of European integration was followed in great detail, and even with a considerable amount of sympathy. Moreover, Yugoslavia entered into contractual relations with the European Economic Community relatively early, and its economic and technological orientation (especially relations with Germany), as well as the growing diaspora after 1964, and especially full openness to Western popular culture, increasingly directed her to that side. ${ }^{5}$ Since 1985, with the government of Branko Mikulić, the arrangement

\footnotetext{
${ }^{3}$ Literature on EU conditionality is rather small concerning the importance and decades of practice. For a long time, Grabbe (2006) was treated as a classic in this field, but like most of the literature, it is pretty apologetic and avoiding tricky (geo)political issues. Recently more critical approaches are being heard and published like Džankić et al. (2019).

${ }^{4}$ A nice collection of papers was recently published as an overview of these ideas (Vučinić, 2013).

${ }^{5}$ For the history of relations between the SFRY and the EEC, see: Đukanović, 2017.
} 
with the IMF, the perestroika in the USSR, and the development of civil society movements in the country, a clear orientation of the state towards the West was formed.

The beginning of the process of the breakup of Yugoslavia coincided with the adoption of the Single European Act in 1986, the completion of the European Single Market, and the transformation of the EEC into the European Union. In doing so, Brussels demonstrated its aspiration to grow into a serious regional actor. So in 1991, for all domestic actors in the Yugoslav crisis, including Milošević and the Serbian leadership, it was only natural for the EU to play an important role as an arbitrator, mediator and provider of good services. The last governments of Yugoslavia (SIV, Savezno izvršno veće) pursued a distinct pro-European policy aimed at intensifying economic and political co-operation with Brussels.

The EEC played an important role during the Peace Conference on the Former Yugoslavia: the Council of Ministers on 27 August 1991 formed the Badinter Arbitration Commission. It was composed of five presidents of the Constitutional Courts of European countries whose views provided an international legal framework for the dissolution of Yugoslavia. A European troika composed of the foreign ministers of Luxembourg (Poos), the Netherlands (Van den Broek) and Italy (De Michelis) led the first mission of shuttle diplomacy in this region. However, very early on, the leadership of Serbia and Montenegro realized that the decisions of these external arbitrators were far from the expected objectivity, observance of international law, and respect for the views and interests of all stakeholders. The decision of the new Croatian leadership to deprive the Serbs of the status of a constituent people in that republic and to reduce them to a minority did not encounter any condemnation or opposition from Brussels, as Germany, Austria and Italy stood firmly behind the separatist policies of the new leadership of Slovenia and Croatia. Opinions No. 1 and No. 10 of the Badinter Commission ${ }^{6}$, which proclaimed the dissolution of Yugoslavia and denied the FR Yugoslavia continuity with the previous state, were not accepted by the leadership in Belgrade. Therefore until 2000, the FRY was not a full member of either the UN or other international bodies. It was only the DOS (Demokratska opozicija Srbije) government that accepted these decisions, that is, the complete concept of dissolution and entered international bodies, presenting it as their supposed great success.

\footnotetext{
${ }^{6}$ The first three opinions were published in Pellet (1992). The next six (4-10) were published in the same journal in 1993, in No. 4 (pp. 74-90).
} 
Already in 1993, with the new President Clinton, the United States entered the great stage of the Yugoslav crisis and completely sidelined Brussels and European actors. The Dayton Agreement was also physically done on American soil under direct American control. But European actors followed US leadership and, starting from 1992, held Belgrade under various sanctions. In all these processes, Brussels and European states had a distinctly anti-Serb stance. In all wars, they supported Serbia's opponents and orchestrated the Kosovo rebellion, which eventually led to the bombing of the FRY and the physical occupation of the southern province of Kosmet. All of this was in line with their earlier geopolitical ideas of repositioning of the Yugoslav space, which usually came from certain English circles and which were formally promulgated after World War II with the establishment of the then internal borders, and the 1974 Constitution in legal terms.

This project boiled down to the old Austro-Hungarian ideas of creating new nations and states on the fringes of the Serbian ethnic space (Toleva, 2016), connecting them and uniting them on an anti-Serb platform, in order to suppress the Serbs from the sea and push them towards central Serbia. At all times, these moves revolved around the old idea of shrinking the Serbs and Serbia exclusively to the frontiers of the territory before the Balkans wars. For this purpose, all measures that threatened the status of the Serbs in the region were tolerated: they were expelled, deprived of their human and status rights, and brutally exposed to assimilation, forced religious conversion, persecution, etc.

In 1999, Serbia was ruined and devastated, and the bombing caused economic damage estimated at 30 to 100 billion Deutsche marks (Terzić and Pašajlić, 2019). At the same time, the arrogance and corruption of the ruling structure prompted citizens to change. With huge foreign assistance and heavy interference in the internal political process, the regime change happened, and a group came to power that set European integration as its goal and framework for reform, modernization and future transition, as well as foreign-policy and value reorientation.

Despite the hopes of the DOS leaders that democratized Serbia would become a partner of the EU and the Western world without Milošević, relations and attitudes toward the state of Serbia and the position and interests of the Serbian people in the region have not changed at all. Moreover, the West expected the new leadership to reimburse its support for having come to power in different ways, namely that Koštunica, Đinđić and the DOS would adopt and implement the framework for the breakup of Yugoslavia that they had defined. No wonder, over time, the prophetic 
speech of Milošević held between the two rounds of the 2000 elections, became a cult one, because it described much more closely the logic of future events than the fairy tales told by opposition leaders.

We should start with the observation that the European Union, in its progress reports on Serbia, always puts geopolitical questions and the assessment of Serbia's adherence to 'the roadmap' at the forefront, and not the Copenhagen criteria, which supposedly should be the basic benchmark for directing and evaluating integration processes. Moreover, there are numerous cases, such as the Brussels Agreement from 2013, in which violations of constitutionality and legality have been encouraged. Two decades after the start of the European integration process, the state of democracy or media pluralism is far worse than it was fifteen years ago or even in the second half of the 1990s during Milošević's rule. Western media and organizations have also begun to talk about this in the last year and a half, but only when the current regime has been seen as trying to avoid completing the total handover of Kosovo.

In this article, starting from the analysis I published five years ago in the book The Illusions of the European Union, I will focus on the basic problems that Serbia and the Serbian people have had with Brussels and the leading EU member states after 2000 (Đurković, 2015).

\section{THE PROBLEM OF TERRITORY AND STATE BORDERS}

In all other cases of EU integrations except Cyprus, the EU dealt with states that had non-disputed territories with a central government exercising full control over each part of its territory. In our case, the FRY (with which Brussels started its negotiating relations after 2000) was not regarded as a single political community, although it was recognized as having an international legal personality. Namely, since 1999, Kosmet has been treated as a separate entity, and de facto the separatist behavior of Montenegro was supported and facilitated, so it was rounded up as a third separate entity. ${ }^{8}$ During the following years, European integrations were used as an instrument for the final decommissioning of the SFRY along its internal borders, as defined in the 1974 Constitution. In the case of Montenegro as

\footnotetext{
${ }^{7}$ The whole speech in Serbian with subtitles in English is available at the following link: https://www.youtube.com/watch?v=knv_nLcrGtI.

${ }^{8}$ In 2003, the EU even formally recommended two-track integration for Serbia and Montenegro.
} 
well as in the case of Kosmet, Brussels has acted in complete opposition to the principle of greater integration and the rapprochement of European peoples (the 'ever closer Union'). While on the one hand, they proclaimed the need for reconciliation and regional integration (including the story of regional ownership), in practice, they supported both separatisms and the further dissolution of the FRY.

\section{A. Montenegro}

Until 2000 and the removal of Milošević, separatism in Montenegro was supported under the alleged justification that a democratic Montenegro was fighting Milošević's authoritarianism and Belgrade's attempt to effectively put Montenegro under its full control. However, Montenegrin nationalism began to flourish just after the removal of Milošević and the coming to power of the Democratic Opposition of Serbia, which in itself included many Đukanović's associates and friends. Already on 29 December 2000, the Government of Montenegro announced in the Pobjeda newspaper in Podgorica a new platform for negotiations on the reorganization of the FRY, in which it first came out with the idea of two independent states. Specifically, it was evident at the time that Milošević was just justification and that the processes had a completely different basis, leading to their further advancement after 2000. ${ }^{9}$ With the support of the US and Brussels, Đukanović continued his project of building statehood and growing separation from Belgrade, which would eventually lead to the controversial referendum of 21 May 2006, when Montenegro became independent. Along the way, some of the most important moments in which Brussels played a key role should be recalled.

In 2001, there were public altercations between the new federal authorities in Belgrade and Podgorica. There had also been numerous attempts to open up discussions between the DOS and the DPS (Demokratska partija socijalista) on various NGO formats and to begin serious negotiations on the transformation of the federal state. However, all these attempts were obstructed by Podgorica, which opted for the factual

\footnotetext{
${ }^{9}$ In a very useful memoir, Momir Bulatović explained that the project of separating Montenegro from Serbia was developed and prepared by the US administration immediately after the Dayton Agreement (Bulatović, 2004). During his first visit to the United States after the Ohio event, he was offered the lead role in the process. When he refused the job, Milo Đukanović accepted.
} 
completion of independence and the promotion of a policy of fait accompli. At the end of the year, the then FRY President Koštunica decided to break away with that situation and to ask Podgorica to hold a referendum as soon as possible, at which the citizens of Montenegro would first decide whether or not they wanted to live in a joint state with Serbia at all.

This happened at a very unfavorable moment for Đukanović himself. Two factors went against his plans. In the internal political life of Montenegro after the April elections of 2001, the DPS was forced to rule as a minority government, dependent on the support of MPs of the Liberal Alliance of Montenegro. This eventually led to the brief formation of the LS Technical Coalition government with the pro-federalist Together for Yugoslavia Coalition in Montenegro, which for the first time threatened the survival of the DPS in power. In addition to this unstable majority, Đukanović was also threatened by the high popularity of Koštunica himself and the DOS in Montenegro, which significantly strengthened the attractiveness of the state union's survival. The general impression was that there was no secessionist majority in Montenegro, so, for example, the Serbian Prime Minister Đinđić (who remained fairly neutral throughout the process) said on 2 January 2002 that he expected a referendum to be called soon, which would end in the rejection of Đukanovićs option. ${ }^{10}$

Precisely at that moment, the EU intervened in the whole process, preventing a referendum at a time when Đukanović would have surely lost it. In January 2002, Brussels began direct mediation aimed at preventing a referendum and preserving a kind of a loose union between Belgrade and Podgorica. This mediation eventually led to the Belgrade Agreement of 14 March of the same year, and the Constitutional Charter on the New Organization of the State Union of Serbia and Montenegro, which was adopted in January 2003. This formally ended the existence of the FR Yugoslavia as an independent, sovereign state and instead created a looser state union which, in Article 3 of its Constitutional Charter, defines as its main goals the integration of the community into the European Union and the harmonization of its legislation with the European Union (Constitutional Charter on the New Organization of the State Union of Serbia and Montenegro, 2003, Article 3). All this effectively enabled Đukanović to consolidate his position and to postpone the referendum for another period.

${ }^{10}$ For a similar statement, see: Bujošević, 2001. 
During the process of negotiating the Constitutional Charter, the 'experts' of the Venice Commission were conspicuously on the side of the Montenegrin negotiators, advocating for a looser union (European Commission for Democracy through Law, 2005).

The next step was the introduction of the so-called double track in 2003, which effectively started treating the European integrations of Serbia and Montenegro as integrations of two separate and divided entities. Following the unsuccessful negotiations between Belgrade and Podgorica on harmonization of the common customs policy towards third countries, Brussels de facto encouraged both sides to give up and keep each other's customs system, which was actually welcomed through the double track of the factual separation of the economic space between Serbia and Montenegro. So, instead of helping to consolidate and reintegrate the community that it had facilitated, which would have been one of its obligations according to the European standards, the EU supported and legalized its actual dissolution.

Moreover, the acceptance of the double track was one of the three key conditions for the issuing of a positive feasibility study in spring 2005 (ISAC/dw, 2005). A shocking second condition was the acceptance of the Constitutional Charter Amendment Agreement, which had been signed only two years earlier. The EU pressured Serbia to accept Đukanović's fraud and refusal to abide by a signed 2002 agreement, which stipulated that elections for the State Union Parliament needed to be held before calling a referendum. At that time, I was part of the state administration and had the opportunity to see firsthand the brutal conditioning of Brussels, first of all in the figure of Stefan Lehne, at the time Javier Solana's Assistant of the High Representative for Foreign Policy. Belgrade was forced to forgo elections, which would have surely consolidated the State Union and diminished Đukanović's legitimacy and to agree to Montenegro holding a referendum first.

All this resulted in a shameful role of the EU during the referendum of the following year when everything was done to facilitate Montenegrin separation. From the behavior of the mediator Miroslav Lajčak, through setting the threshold at only 55\% of voters in favor of independence, then through the unilateral action of the chairman of the referendum commission, another Slovak, František Lipka, and tolerating all electoral irregularities, including announcing the alleged results five minutes after the referendum ended. ${ }^{11}$ So, everything that Brussels did after 2000 in the case of Montenegro

${ }^{11}$ This shameful role was played by Belgrade's Marko Blagojević, who followed the regularity of the referendum in front of the 'objective' NGO CESID. 
was contrary to their principles and led to the further disintegration of the former Yugoslavia.

After the separation of Montenegro, Đukanović's regime was supported in all of its actions to undermine the Serbs' rights. The EU is completely indifferent to the fact that the Serbs, who make up a third of Montenegro's population, live in that country without any rights. Moreover, Belgrade, through its demands for improving regional co-operation, is asked to forget about the Serbs outside Serbia and to accept their violent assimilation into new surrounding nations.

\section{B. Kosovo}

Discussing the normative framework of enlargement in my book The Illusion of the European Union, I also cited the previous practice of enlargement as the basis for Brussels' expected attitude towards the candidate. From this perspective, the Cyprus case had to be a template for treating the Kosovo case in Serbia's integration process. As it is well known, since 1974, the Nicosia government has not exercised any factual control over the northern part of Cyprus, which survives as the unrecognized Turkish Republic of Northern Cyprus. During the accession process, there were no double tracks in Cyprus, but the entire territory was treated as part of a sovereign and integrated state. Also, there was no violently imposed negotiation or insistence that the problem must be 'solved' at all costs to speed up integrations. Moreover, after the failed peace initiatives, Brussels simply registered the fact that the conflict could not be overcome because the Turks from northern Cyprus did not want to return to the sovereign jurisdiction of the Nicosia regime. It left the factual state of division in the field and accepted the entire territory of Cyprus into EU membership. ${ }^{12}$

In the case of Kosovo, which is, in fact, very similar to the Cyprus problem, Brussels did precisely the opposite. Moreover, European officials were often willing to claim that the Cyprus case was the reason they did not want the same thing to happen again and to let Serbia get full membership with a part of its territory that it did not actually control.

The essential difference in the different treatment of these two very similar cases lies in the different histories of their occurrence and the different position of the stakeholders in them; the interests of the most

${ }^{12}$ For more information on the integration of Cyprus in the EU, see: Shaelou, 2010. 
serious great powers were also important. The partition of Cyprus was made by the Turkish state to the great resentment of the Western allies, which even imposed an arms embargo on it. However, because of Turkey's great strategic importance for the US and NATO foreign policy, this factual division is partly tolerated, but only insofar as it does not anger another ally, Greece, who is otherwise still allocating big money for international lobbying in favor of maintaining the integrity of Cyprus and fighting for the reintegration of the entire island under a single government.

In the case of Kosovo, however, the partition of Serbia arose after the war that NATO and all the major Western powers had jointly launched against Serbia. From the beginning, the goal was separation, and Serbia had neither the means of lobbying nor any opportunity to prevent that factual separation. Even after 2000, Brussels fully put into operation these earlier policies, doing the opposite of what was done in the Cyprus case or in all other cases in which it had contributed to resolving the minority issue peacefully through some form of autonomy in the domicile country as an indisputable international legal entity.

So, in fact, we have witnessed that even after 2000, Kosovo received continuous assistance to become a fully-fledged state, and later the same actors would argue that a 'changed situation on the ground' was crucial, so a return to the old state of things was not possible. Even the pogroms of 17 March 2004 and the forced displacement of the Serbs, with the destruction of hundreds of churches, religious sites, all traces of Serbian culture and even cemeteries, were evidently tolerated.

Moreover, just after the pogrom, Brussels and the major European powers also participated in the revision of the previous normative framework, which was defined by the thesis 'standards before status'. The objective was to achieve certain standards in the field in a number of areas, such as the return of refugees, home reconstruction, institution building, etc., and only then to start considering status. However, since 2004, the rhetoric has been changing rapidly, and already the following year, pressure began to be exerted to resolve the status issue as a matter of urgency. Already in November 2005, the Security Council appointed Martti Ahtisaari as the main mediator in the negotiations, and Albert Rohan was delegated on behalf of the European Union as his deputy. Negotiations began in Vienna in February 2006, and after a farce that lasted until November of the following year, the negotiations were officially finished without success. Throughout the period, it was clear to all participants that the West was merely seeking some form of independence with minority protection for the 
Serbs in an independent Kosovo, and that there was no factual negotiation. All Belgrade's proposals were rejected, and the Kosovo Assembly declared independence on 17 February 2008, which was immediately recognized by all major Western powers which had previously played the role of allegedly 'objective negotiators'.

It should be noted that participation in these Vienna negotiations was imposed on Belgrade as another condition for the continuation of European integration, especially as part of the struggle to sign the Stabilization and Association Agreement. ${ }^{13}$ After independence was recognized and supported by as many as 22 out of $27 \mathrm{EU}$ member states, Brussels continued its pressure on Belgrade to slowly align its Kosovo policy with the Ahtisaari plan and to actually accept independence. The acceptance of the arrival of the EU mission EULEX followed, which took over operational control of Kosovo by replacing the United Nations mission in accordance with the Ahtisaari plan. The Tadić's Administration also accepted the factual integration of the Serbs south of the Ibar into the state system of independent Kosovo, but in 2011, it refused to do so with four northern municipalities. That is why, with the help of the West and Brussels, a new administration was installed instead of Tadić, with Nikolić and Vučić at the helm. ${ }^{14}$ They also accepted the agreement on integrated border management that established a real border between Serbia and Kosovo, and the Brussels Agreement, which opens space for the full reintegration of four municipalities into the system of the Kosovo government. This was a key condition for obtaining candidate status and for opening formal membership negotiations with Brussels.

As a key EU country (others follow), Germany soon began demanding that Belgrade and Pristina sign a good neighbor agreement, and there are more and more voices explicitly stating that Serbia will have to formally, before its eventual admission into the EU, recognize Kosovo's independence. ${ }^{15}$

\footnotetext{
${ }^{13}$ At that time, the author was part of the cabinet of the Serbian Prime minister and witnessed the constant pressures coming from the Contact group, of brutal political conditionality and faking of the negotiations.

${ }^{14}$ On the very day of the election on May 20, 2012, the European Commission published on its website a note congratulating Nikolić on winning the elections three hours before the voting was over (Gaf EU, 2012).

${ }^{15}$ Moreover, we also remember the famous performance of German Ambassador, Andreas Zobel, who publicly warned Serbia in 2006 that if it did not recognize the independence of Kosovo, it could even lose Vojvodina and Sandžak. Western officials have never issued such 'warnings' to any other candidate country (E. V. N., 2007).
} 


\section{THE HAGUE TRIBUNAL}

Until 2011 and Mladić's extradition, co-operation with The Hague Tribunal (officially the International Criminal Tribunal for the former Yugoslavia, ICTY) was the first and key condition for the continuation of Serbia's European integration. Although this complex set of issues was governed by the rule of law provisions, it was essentially a geopolitical condition par excellence. Brussels and the so-called international community accused the entire political and military leadership of Serbia, the Republic of Srpska and the Republic of Serbian Krajina in the 1990s, at a time when the Serbs refused to accept the dictated geopolitical repositioning of the Balkans and therefore entered into direct conflict with the West. As a result, Brussels demanded that the new authorities be apprehended and handed over to an 'independent and objective' tribunal in The Hague.

The same court acquitted Ramush Haradinaj (military leader of UCK, the Kosovo Liberation Army) and Naser Orić (Bosniak military commander of the Srebrenica region, guilty for massive crimes over Serbian civilians), and in the end, no one was convicted of the crimes in the Operation Storm*. This kind of pressure and conditioning in the case of Croatia was comparatively milder and more measured. In the Bobetko case, they let the former Commander-in-Chief of the Croatian Army eventually die in Zagreb, and Croatia did not suffer any consequences for not extraditing him. Only in the case of Gotovina, there were more serious pressures and conditions, but in the end, the whole process was completed without a final conviction, and Croatia became a member of the Union without major problems.

In the case of Serbia, however, The Hague Tribunal was stressed as the first and foremost condition, despite all other major economic and political problems in the country. This clearly defined Brussels' priority in relations with Serbia: ending the war with Serbia, accepting full defeat, and punishing gravely the 1990s Serbs' leadership. A positive feasibility study was obtained primarily after a series of extraditions of military and police leaders conducted by Koštunica's cabinet in early 2005. EU candidate status was obtained several months after Mladić's extradition.

Now, however, it is suggested that further conditions of integration will be the introduction of the consequences of their trials (and such an interpretation of recent history) into school textbooks. For example,

\footnotetext{
* Military operation of the Croatian Army in July 1995, in which hundreds of thousands of Serbs were cleansed from Croatia, the former the Republic of Serbian Krajina.
} 
textbooks in Serbia would have to teach children that an act of genocide was committed in Srebrenica in 1995, which would mean that the children are being taught the Western version of what happened in the former Yugoslavia. ${ }^{16} \mathrm{I}$ am not aware of any other case in the forty-year-long history of its enlargement practice in which Brussels has conditioned the entry of a country by changing its school curricula and revising textbooks.

\section{CHANGING CONSCIOUSNESS}

Closely related to the previous point is the now (in)famous and often repeated condition of Germany, as the most dominant force in the Union, on the so-called 'change of consciousness' in Serbia and among the Serbs. At the 2010 NATO conference, the then German ambassador to Belgrade, said the following: 'I have to criticize the authorities in Serbia for using terms such as NATO bombing' themselves! Imagine walking down Prince Milos Street and asking your child, "Dad, who did this?" You will answer him: "NATO"! So what do you expect that kid to think about NATO? In contrast, as a young man in Germany, I watched the ruins in my city - but I didn't hate the one who did it because there were those who could tell me why it was done' (Maas, 2010). ${ }^{17}$

Mr. Maas then demanded that the Serbian leadership work to change the consciousness of its citizens, after which they would accept the 1999 illegal bombing as something that was done in our interest. He, therefore, equated Milošević's behavior with that of Hitler's Germany and demanded that Serbia should internalize and adopt this 'fact' as part of its collective memory. In early 2012, German parliamentarians demanded that the authorities in Serbia also help change the consciousness of the Kosovo Serbs.

As in the previous segment, this is about accepting defeat and internalizing the dictates of the victor as part of its altered consciousness, and not about the Copenhagen criteria. In all this, it is easy to recognize the recurrence of the legacy of frustration over the defeat of Germany in the two

\footnotetext{
${ }^{16}$ On 16 November 2012, Minister Rasim Ljajić spoke openly about it after the acquittal of Gotovina and Markač. He resignedly said that the cooperation with ICTY would be reduced to the technical level and that all the programs discussed, such as, for example, the introduction of the ICTY verdicts into textbooks, would be suspended for the time being.

${ }^{17} \mathrm{He}$ stated this at the pro-NATO conference held in Belgrade on 28 October 2010. Though all newspapers reported about it at the time, today it is all unavailable after serious internet forensic that someone has done.
} 
world wars. All this again has nothing to do with the current practice or normative demands of EU enlargement.

\section{VENICE COMMISSION}

The behavior of the Venice Commission during two important 2006 processes was extremely biased, and at the least strange and unusual. The Venice Commission is an organ which is a kind of the Council of Europe subsidiary body and which - formally speaking - is not really part of the structure of the European Union. However, during the process of preparing the referendum in Montenegro and during the discussions regarding the adoption of the 2006 Constitution of Serbia, it has worked closely with the Union bodies, which politically addressed these processes in accordance with the 'legal' recommendations and opinions of the Venice Commission. Its opinion on the 2006 Constitution of the Republic of Serbia remained a kind of lasting testament based on which the Brussels authorities, since its adoption, have sought to change that Constitution.

In the run-up to the Montenegro referendum, the Venice Commission and Brussels came up with the rather strange figure of $55 \%$ as the supposedly sufficient majority to legitimately determine Montenegro's readiness for independence ${ }^{18}$. At the same time, they revoked the voting rights of Montenegrin citizens living in Serbia.

But even besides this process of the territorial shrinking of the state covered in the first part of this text, the 'Venetians' continued to interfere with the order of Serbia. The opinion delivered at a session of 17 and 18 March 2007 adopted by Brussels as a landmark for the future revision of the constitution, is filled with extremely unexpected and malicious remarks that affect the territorial and institutional structure of the state, as well as the identity of the state and the Serbian people as its majority. For example, in item 12 of this opinion, the Commission condemns Article 10 of the Constitution of the Republic of Serbia, which specifies that the official language of the Republic of Serbia is the Serbian language and Cyrillic script. Allegedly, with such a provision and omission to include the Latin script explicitly in official use, Serbia is threatening minority rights (European Commission for Democracy through Law, 2007).

\footnotetext{
${ }^{18}$ The Canadian Supreme Court in 1998 passed a ruling in which it defined a clear majority as a necessary condition for the secession of Quebec. 55\% could hardly be accepted as such a clear majority.
} 
This statement, as well as other remarks (e.g., regarding autonomy), carries a pronounced politicization, as rightly pointed out in expert analyses by Vladan Kutlešić (2007) and Slobodan Antonić (2007), among others. I will not repeat their arguments here, but the reader can look up these texts (as well as the opinion itself) and see for himself the malicious comments and the unfounded remarks that serve to further condition Serbia. It is particularly interesting to put this opinion in a comparative framework. Kutlešić (2007) notes: 'In this connection, it is interesting that, as far as constitutions are concerned, the Commission has declared its opinion on the constitutions of the following countries: Georgia, Montenegro, Ukraine, Bosnia and Herzegovina, Macedonia, Kyrgyzstan, Moldova, Armenia, Chechnya, Liechtenstein, Azerbaijan, Romania, Croatia, Slovenia, Mozambique, Belarus, the Republic of Srpska and Serbia. The above list is interesting for two reasons: first of all, because during that same period the constitutions were changed, adopted or amended in other, at least formally similar states: Bulgaria, Estonia, Latvia, Lithuania, Poland, Slovakia, the Czech Republic and Russia, and their constitutions were not subjected to consideration by this commission. Second, and perhaps more important, is that in the same period, ten other so-called old European democracies adopted new constitutions (Switzerland 1999, Finland 1999, Greece 2001 and the Netherlands 2004) or changed their existing ones (e.g. Italy repeatedly until 2002, Belgium and Ireland repeatedly until 2004 and France in 2005) but their constitutions were not subject to review by this commission'.

We note, therefore, that the constitutions of only three countries that have recently become members have gone through the analysis of the Venice Commission. We also see that the Commission avoids giving opinions on the constitutions of the existing EU member states as well as on those candidates that are not 'adequate' for evaluation because of the geopolitical interests of the major Western powers.

\section{MINORITY ISSUES}

In 2005, at a time when the Serbian administration was struggling to get a positive feasibility study, one of the biggest obstacles was the issue of Roma readmission. Unlike the Hague condition that dominated the media, negotiations on this issue were conducted far from the eyes of the public. Very few documents and traces were left about all this, and the author of this text has not been able to access the data on the official or unofficial number of people that Serbia had to accept and provide them with social welfare in order to accomplish this step in European integration. From direct 
conversations with the people who ran the Office for Minority Affairs in the administration at the time, I learned that the Brussels pressures were brutal and that they were not without grounds for speculation that Brussels sought the readmission of not only Roma from Serbia but also of many that did not have any Serbian documents.

Generally speaking, although the FR Yugoslavia adopted a very liberal Minority Law immediately after the regime change on 5 October 2000, and although Serbia today has one of the 'most progressive' minority policies in Europe, which includes remarkably wide rights for national councils, minority language education, etc., this country constantly suffers the pressures as if it were truly endangering certain minorities. The European Parliament (2012) has repeatedly tabled and adopted resolutions on alleged threats to minority rights in Serbia or criticized Serbia's inadequate attitude to the minority issue. We have also seen from the remarks of the Venice Commission that it is maliciously seeking any reason to reprimand Serbia and warn against its minority rights policies.

At the same time Bulgaria, for example, does not recognize national minorities at all; Croatia has become a full member despite refusing to address the issue of occupancy rights and return of the Serbs; and the ethnic Serbs in a number of neighboring non-EU countries cannot receive even a portion of their minority rights in Serbia. This geopolitically inspired flexibility on behalf of Brussels is best exemplified by the cases of the Baltic republics, which since 1990 have systematically violated and denied human and ethnic rights, above all those of the Russian minority, but also of all other minorities living in the territory of those states. They have been living without citizenship, regular passports, the right to vote in elections and the right of protecting their ethnic and national identity for more than two decades. All this has never been condemned by Brussels, and fifteen years ago, these countries were given full EU membership despite their radical discrimination against a large number of their citizens (Гапоненко, 2012).

\section{PRIVATIZATON}

In mid-June 2011, the Brussels Administration sent a letter to the Government of Serbia requesting an examination of more than twenty privatizations carried out in Serbia since 2000. In the coming months, 24 'controversial privatizations' crystallized, and the next two governments in Serbia were also asked to investigate and make a resolution on those issues (D. C. V., 2013). 
Privatization has been associated with some controversy in almost all Eastern European countries, but I do not know of an example that Brussels called for a reconsideration of privatizations as a condition for the advancement of integration. The aim everywhere was to strengthen the private sector and to bring the market economy into operation as soon as possible, and any backward move, as a rule, could only slow down this process. In any case, a very selective choice of contentious privatizations is evident. A foreign company was involved in only one case (Sartid). In all other cases, the potential culprits (besides members of the administration) are major Serbian tycoons. At the same time, there is no mention of the potentially controversial privatizations whose actors were Croatian and Slovenian companies, for instance. A very well-known and suspicious transaction from 2005 was Agrokor's purchase, under suspicious circumstances, of a two-third ownership stake in the edible oil manufacturer Dijamant. ${ }^{19}$ However, if it is known that the European Bank for Reconstruction and Development has repeatedly invested its capital in Agrokor, then it becomes clear why the Brussels Administration overlooks the illegalities of this company and puts pressure on the big Serbian tycoons.

\section{CONCLUSION}

Therefore, besides the standard conditions, Serbia also faces a number of conditions that are not imposed on other candidates. Knowing the history of enlargement and the case of Turkey, for example, one comes to the logical conclusion that geopolitics in the process of Serbia's European integration is much more important than the current normative and inherited enlargement practices, and that this thesis cannot be simply rejected by the standard claim that the EU has lifted the ladder after $2004^{20}$. For those who have any doubts concerning general attitudes still dominating toward the Serbs, we recommend any overview of the western propaganda during the nineties and after. ${ }^{21}$

${ }^{19}$ The prosecutors and the police have repeatedly tried to tackle the suspicious sale of shares outside the stock market, but the investigation never ended.

${ }^{20}$ The developments around Ukraine and the way in which the EU-Ukraine treaty was signed on 27 June 2014, are extraordinary evidence of the revived geopolitical background of the EU enlargement policy.

${ }^{21}$ For example, Vuković (2018) offers a comprehensive collection of media, political and academic narratives. 
Serbia is treated as a defeated adversary, and the 'European' framework is used to complete the geopolitical re-arrangement of the space that Serbia resisted in the 1990s. However, various elements that lead to the undermining of the identity of the majority of people and the state are also added to this.

The process of European integration of Serbia is undoubtedly taking place as a process of permanently setting new atypical conditions, leading to further destabilization and weakening of the state, instead of strengthening it in accordance with the Copenhagen criteria. The goal is obviously to keep us in the process as long as new conditions are constantly being put in place.

However, there are logically three issues that cannot be heard in the Parliament or the relevant debates of our political elite:

1. In particular, in the light of current French attitudes toward enlargement, is the goal of the great Western countries at all for Serbia to ever become a member?

2. What is the geopolitical and identity price that Serbia is prepared to pay, knowing what the real conditions for potential membership are?

3. What are the practical consequences of Serbia's possible withdrawal from Eurointegration?

All these dilemmas become even more pronounced when the Republic of Srpska, as a state entity of the Serbian people, is included in the equation. As is well known, conditionality in the process of European integration of Srpska and $\mathrm{BiH}$ is reduced to 'building a more efficient state', which is a euphemism for additional centralization and transfer of competencies from the level of Banja Luka to the level of Sarajevo.

Finally, the area inhabited by the Serbian people, but also of all other nations in the Balkans, is being vacated (depopulated) at the moment and becoming demographically and security threatened as EU countries take away all the labor force they need. This is all part of the European integration process, in which countries have to come to terms with being left without population. Another part of the story is the compulsion to embrace an antifamily value system that logically leads to a decline in natural population growth. In the book The Illusion of the Europan Union, I cited as my main argument against European integration the very system of values and normative policies that the EU is forcibly exporting to our countries (Đurković, 2015). Suffice it to say that the creation of a family policy in the EU is dominated by Sweden and its suicidal legacy of policies initiated by Alva Myrdal. 


\section{REFERENCES}

Antonić, S. (2007). Venecijanska komisija i ćirilica [Venice Commission and the Cyrillic]. Nova Srpska politicka misao, retrieved from http:// www.nspm.rs/srbija-medju-ustavima/venecijanska-komisija-icirilica.html?alphabet=1. Accessed 12 December 2019.

Bujošević, D. (2001, April 26). Beograd kulira [Belgrade is Chilling Out], retrieved from http:/ / www.nin.co.rs/2001-04/26/17678.html. Accessed 13 December 2019.

Bulatović, M. (2004). Pravila ćutanja [The Rules of Silence]. Belgrade, Narodna knjiga.

Constitutional Charter on the New Organization of the State Union of Serbia and Montenegro, 2003, retrieved from http:/ / www.arhiva.srbija.gov.rs /vesti/2003-02/05/333116.html. Accessed 12 December 2019.

D. C. V. (2013, December 28). Izveštaj o 24 privatizacije [Report on 24 privatizations], retrieved from https:/ / www.vreme.com/cms/view. php?id=1162898. Accessed 14 December 2019.

Гапоненко, А. (Ed.) (2012). Дискриминация русских в странах Балтии: причины, формы, возможности преодоления [Discriminations of Russians in the Baltic Countries: Reasons, Forms, Possibilities to Overcome]. Moscow - Riga, Московское бюро по правам человека.

Đukanović, D. (2017). SFR Jugoslavija i Evropska ekonomska zajednica: od uspešne saradnje i potencijalnog članstva do suspenzije svih sporazuma [SFR Yugoslavia and the European Economic Community: From Successful Cooperation and Potential Membership to the Suspension of All Agreements], retrieved from https://yuhistorija.com/serbian/ medj_politika_txt00c1.html. Accessed 12 December 2019.

Đurković, M. (2014). Evropske integracije Srbije između normativizma i geopolitike [European Integration of Serbia Between Normativism and Geopolitics]. Kultura polisa, 11, pp. 89-108.

Đurković, M. (2015). Iluzija Evropske unije [Ilusion of European Union]. Belgrade, Catena mundi.

Džankić, J., Keil, S. \& Kmezić, M. (2019). The Europeanization of the Western Balkans: A Failure of EU Conditionality. London, Palgrave Macmillan.

E. V. N. (2007, April 13). Ambasador Cobel prevršio meru [Ambassador Zobel Crossed the Line], retrieved from https:// www.novosti.rs/vesti/ naslovna/politika/aktuelno.289.html:196668-AMBASADOR-COBELPREVRSIO-MERU. Accessed 14 December 2019. 
European Commission for Democracy Through Law. (2005, December 19). Opinion on the Compatibility of the Existing Legislation in Montenegro Concerning the Organization of Referendums with Applicable International Standards, Opinion No. 343/2005. European Commission for Democracy Through Law, Strasbourg.

European Commission for Democracy Through Law. (2007, March 19). Opinion on The Constitution of Serbia, Opinion No. 405/2006. European Commission for Democracy Through Law, Strasbourg.

European Parliament. (2012, March 29). European Parliament resolution of 29 March 2012 on the European integration process of Serbia (2011/2886(RSP)), Enlargement report for Serbia, P7_TA-PROV(2012) 0114. European Parliament, Brussels.

Gaf EU, čestitka Nikoliću 3h ranije [EU's Gaf, congratulations to Nikolić 3 hours earlier]. (2012, May 20), retrieved from https:/ / www.b92.net/ info/izbori2012/vesti.php?yyyy $=2012 \& m m=05 \& d d=20 \& n a v \_i d=61097$ 3. Accessed 13 December 2019.

Grabbe, H. (2006). The EU's Transformative Power. London, Palgrave Macmillan. ISAC/dw. (2005). Studija izvodljivosti [Feasibility study], retrieved from https://www.dw.com/sr/studija-izvodljivosti/a-3863602. Accessed 13 December 2019.

Kutlešić, V. (2007). Da li je promena Ustava Srbije 'izuzetno teška i vrlo složena'? [Is the Change of Serbian Constitution 'Extremely Difficult and Very Complex'?], retrieved from http://starisajt.nspm.rs/debate_ 2007/2007_kutlesic3.htm. Accessed 13 December 2019.

Maas, W. (2010, October 28). Mas: Srbi moraju svojoj deci da objasne da je bombardovanje bilo ispravno [Maas: Serbs Have To Explain to Their Children that The Bombing Was Right], retrieved from https:/ / groups. google.com/forum/\#!topic/siem/AHOnhLy9rV8. Accessed 14 December 2019.

Pellet, A. (1992). The Opinions of the Badinter Arbitration Committee: A Second Breath for the Self-Determination of Peoples. European Journal of International Law, 3, pp. 178-185.

Shaelou, S. L. (2010). The EU and Cyprus: Principle and Strategies of Full Integration. Boston - Leiden, Martinus Nijhoff Publishers.

Terzić, J. \& Pašajlić, S. (2019, April 27). I dalje ne znamo kolika je šteta od NATO agresije [We Still Don't Know the Damage of NATO Aggression], retrieved from http://www.rts.rs/page/stories/sr/78\%D0\%B4\%D0\% 
B0\%D0\%BD\%D0\%B0/story/2850/analize/3504405/i-dalje-ne-znamokolika-je-steta-od-nato-agresije.html\%20G17. Accessed 13 December 2019.

Toleva, T. (2016). Uticaj Austrougarske na kreiranje albanske nacije [AustroHungarian influence on the creation of the Albanian nation]. Belgrade, Filip Višnjić.

Vučinić, M. (Ed.). (2013). Наш поглед на Ebpony [Our View on Europe]. Belgrade, Službeni glasnik.

Vuković, S. (2018). Srbi u narativu Zapada: 'Humanitarna' NATO intervencija [Serbs in the Narrative of the West: NATO's 'Humanitarian' Intervention]. Novi Sad, Izdavačka knjižarnica Zorana Stojanovića. 